\title{
SERPINB4 wt Allele
}

National Cancer Institute

\section{Source}

National Cancer Institute. SERPINB4 wt Allele. NCI Thesaurus. Code C148324.

Human SERPINB4 wild-type allele is located in the vicinity of $18 \mathrm{q} 21.33$ and is

approximately $7 \mathrm{~kb}$ in length. This allele, which encodes serpin B4 protein, is involved in the inhibition of serine proteinases. 